\title{
Adaptive variation in extent and timing of growth of Scottish Scots pine (Pinus sylvestris Linn)
}

\section{Anandan Govindarajulu*}

University of Edinburgh and Centre for Ecology and Hydrology, UK

*Corresponding author: Anandan Govindarajulu, MSc in Forest Geoscience, University of Edinburgh \& Centre for Ecology and Hydrology, UK, Tel: 91-9597149700; Email: anandangrowmore@gmail.com

Rec date: Mar 29, 2014, Acc date: Apr 17, 2014, Pub date: Apr 25, 2014

Copyright: ( 2014 Anandan G. This is an open-access article distributed under the terms of the Creative Commons Attribution License, which permits unrestricted use, distribution, and reproduction in any medium, provided the original author and source are credited.

\begin{abstract}
Local adaptation is a key consideration for forestry related activities, particularly when seed is transferred from one seed zone to another for afforestation. Locally adapted trees may show differences in growth when planted in sites other than their origin. Scots pine is one of the most valuable commercial timber trees with higher rate of growth. Although growth differences have been noted in the past, the extent to which Scottish Scots pines are locally adapted at the population level has remained unclear. In this dissertation, some aspects of local adaptation in pine are discussed and previous work is reviewed (essay review) and then (research paper) an experimental trial is presented in which genetic differences among populations and families from the Scottish Scots pine distribution are tested using growth as a measure of performance. Differences are related to climatic variables from the sites of origin of the seed. Finally, the role of provenance/progeny trials or common garden tests in researching local adaptation is also discussed.
\end{abstract}

Keywords: Scottish scots pine; Adaptive variation

\section{Introduction}

We are living in an era of global warming and facing a threat to nature that human beings have not experienced previously. Forestry offers one option for mitigating the threat and various attempts are being made to improve world forest cover as a means of extracting $\mathrm{CO}_{2}$, a greenhouse gas, from the atmosphere. For that purpose, widespread planting of trees is being carried out, or being planned. However, it is clear that the climate is changing and, for long term sustainability of these tree-planting efforts, the responses of the trees to the varying climatic conditions are very important to understand.

For almost 200 years foresters have been testing seeds and seedlings from various provenances in common garden experiments, often at multiple sites. Such trials remove environmental differences and allow assessment of the genetic component of variation [1]. They have been trying to find the most productive seed source and good high quality timber output for each area of their interest. An individual species can grow in wide range of climatic conditions but the optimal phenotype may change over short distances.

\section{Local Adaptation}

Local adaptation is well-characterized in numerous tree species, and trees usually perform best at or near their home sites. Local adaptation can be defined as evolution, through natural selection, of traits that have high fitness in the environment conditions specific to a population. Local adaptation can occur due to many selective factors such as climates, soils and parasites [2-4] and different traits can respond to natural selection. It is clear from Darwin's theory that forces of natural selection differ in spatial and temporal basis and that leads to an expression of genotype that fits into the climate space, part of the process of, survival of the fittest. Phenotype is the output of the genotype and environment interactions. Various experiments such as fossil pollen record and genetic data highlight a giant capacity for range shifts [5]. Anecdotal evidence of the capacity of forest trees shows trees adapt rapidly to new environments including the development of steep genetic clines during post- glacial migration [5]. Initial pollen records showed post glacial migration was up to $200 \mathrm{~m}$ per year. Divergent selection forces a local population to evolve traits that favour growth and reproduction under the local conditions, which is referred to as habitat. In the absence of other factors, the local population fits better the local condition than the other populations from other habitats. This is the pattern and process that leads to local adaptation [6]. If a small group or small founder population is established the permanence and phenotypic flexibility of most tree species may allow for the perseverance of these nucleated populations. The adaptation of these newly differentiated populations may require genetic source to provide variation from long distance pollen flow for the establishment of populations sufficiently large and genetically variable to be viable and become locally adapted $[7,8]$. Once the expression of any gene, to the local set of divergent selection factors, is fixed, then we expect the gene will be retained as long as the environment does not change much [9]. In the common garden experiments detection of mean fitness of local populations across a set of habitats is the main focus. We should also understand that all populations within the local conditions or spatially separated entire populations may not express similar phenotypes as they are genetically distinct. Species like Scots pine (Pinus sylvestris) may be distributed across broad climatic conditions, but their genotype changes over very short geographical distances. For example, populations of tree species may differ in quantitative traits even if they are separated by short distances possibly only one meter away. Genetic variations within and among populations help adaptation to the new environmental conditions $[10,11]$. 


\section{Local adaptation in trees}

These local adaptations are specific to the population of that particular environment and we cannot expect throughout all population. These characters are formed as a process of natural selection and show a population's ability or fitness to withstand and survive in that uncommon environment compared to other populations. In the life cycle of trees, endodormancy is one of the important stages when the seedlings try to escape unfavourable conditions such as cold, frost days by avoiding it by undergoing a period of inactivity. Prolonged nights and minimum night temperatures are the major crucial factors for inducing endodormancy [5]. Later on, endodormancy is released by chilling effects. Just above the freezing point of water the seedlings are releasing endodormancy [5]. After release from endodormancy the next stages of the growth cycle occur. Steps involved in growth initiation are: cold dissimilation, initiation of mitotic activity in the terminal bud followed by initial growth and occurrence of bud flush as a respond to warm temperatures [12,13]. Threshold temperature and duration of warm period vary within and among species [14]. Apart from this the other most important environmental factors controlling annual growth cycles are photoperiod and temperature, although soil moisture and nutrient availability are important as they react and interact with these cues $[9,14]$. Nutrient status of the soil is not well known for its interaction with cold hardiness as it is still unclear or has very minimal effects [13].

The timing of growth cessation is another important way in which trees adapt to local environment. In many tree species, a combination of photoperiod and temperature sum plays a determinant role in growth cessation. In the case of pines temperature is the only key factor determining the timing of growth cessation. Other simple adaptations, which take care of timing of growth during the spring when the temperature is favorable, are chilling requirement and flushing requirements. The well-developed dormancy capability of trees endodormancy [1], clearly indicates that they take advantage of climatic conditions that favour their growth and that mitigate cold damage during the winter. Population differentiation is generally stronger for cold adaptation traits than for other quantitative traits. Some woody perennials have great potential to withstand cold temperatures. In extremes, some species can survive in liquid nitrogen $\left(-196^{\circ} \mathrm{C}\right)$ when dormant, temperatures that would kill the same tree when they are actively growing [15]. The process of tolerating extreme cold involves integrated expression of many qualities and genes, mostly the reaction to environmental factors such as photoperiod and temperature. For instance boreal and temperate trees are usually able to survive at temperatures as low as $-80^{\circ} \mathrm{C}$ when they are in their winter state [16].

The temperate tree's annual life cycle contains various traits that are in some way related to cold hardiness. The steps involve in this process are:

- Growth cessation and bud set;

- Initiation of cold acclimation;

- Development of endodormancy;

- Development of maximum cold hardiness;

- Endodormancy release via chilling;

- Loss of cold hardiness; and

- Initiation of primary growth and vegetative bud flush.
In preparation for dormancy, mitotic activity starts to reduce. At the same time we cannot expect bud set because the association between bud set and reduced mitotic activity is even lower, especially in older trees. In the case of young seedlings, bud scales start to form at the middle of the summer as an indications of growth cessation which may take three months [17]. Meanwhile, shoot enlargement can be continued at time of scale formation which is related to the sub-apical meristem and cell elongation.

In the growth process species may be classified into two kinds. One is seasonally indeterminate and the other is determinate. In the seasonally indeterminate species early growth i.e. primary growth occurs in one or more flushes. Elongation of pre-formed or neoformed stem units takes place in one or two times in the same growing season without any formation of bud set and undergoing endodormancy or even growth cessation. Growth termination occurs on experiencing long nights, in other terms short days, and low nighttime temperatures which consists setting of buds or abscission of terminal tip [18]. But in the seasonally determinate species growth occurs only once in the growing season and ends with formation of bud and growth cessation. In seasonally determined species the growth ends early in the growing season immediately after the completion of development of pre-existing stem units. Subsequent to formation of bud set, new stem units are formed which will be growing the next growing season. The actual timing of the bud set depends on the number of stem units in the terminal bud and the time required or taken for elongation of the shoot, and is not governed by prevailing environmental conditions [14]. The tendency for secondary growth in the same growing season is genetic; whether or not it happens depends on individual and site variations $[19,20]$. Free or secondary growth is immediate formation of axial bud which occurs without an intervening period of dormancy at the same growing season. In Scots pine shoot elongation finishes by mid-summer. Then the maturity of other parts starts such as elongation of needles and maturation, stem diameter growth, bud tissue formation and maturation.

\section{Genetic Variation}

Genetic variation occurs at various levels as every tree is genetically different. There is variation between trees as not one tree is genetically identical. However, variation also occurs between small family groups of closely related trees and, on a larger scale, between different locations which differ in topography, soil type and wind direction, all of which have an impact on gene flow. Previous studies on the genetics of Scots pine have shown that natural selection has driven local adaptation to biotic and abiotic conditions while gene flow opposes it. From previous experience with other pine species, it is known that it is difficult to predict the actual degree of local adaptation that will develop [21,22]. Nearly all biochemical variation is observed within rather than between populations, for example in traits related to climatic factors such as bud burst and set date, cold damage resistance, survival of young seedlings, rate of growth etc. [23]. At the same time different species adapt differently to the same ecological variations. According to previous work, genetic variation among the Scots Pine populations in Scotland is very small [24]. On average, $2 \%$ of total isozyme variation in Scotland is accounted for by differences among populations [25]. This highlights that the fact that gene flow has been considerable and has restricted the extent of divergence for selectively neutral markers by genetic drift [26]. 


\section{Pine Adaptation}

In North American trials, locally adapted forest tree species have shown higher fitness than the non-local populations in local climate $[27,28]$. Populations from more central locations are adapted to the current climatic conditions better than the populations from the border or margin areas because of asymmetric gene flow from central to peripheral locations [29]. For example, in North America, [30,31] found that northern populations of lodge pole pine inhabit colder than optimal climates for their mean phenotypes, although this result depends to some extent on the method used to anchor response functions when climatically extreme sites are lacking [32]. Found that geographically isolated populations of Sitka spruce are better adapted to their environment in terms of growth rate and phenology combined, than peripheral populations from the continuous species range, suggesting that gene flow restricts local adaptation in the latter.

It is possible to get better growth rate in some or all populations if they are transferred to warmer, cooler or drier areas from their site of origin $[2,27]$. Heritability for phenological traits and cold hardiness are typically higher than for growth rate, but there is usually more within population phenotypic variation for growth than for phenological traits [33].

Time is one of the important factors for adaptation in case of tree especially pines. Species which have been present in the particular area for long periods of time are well experienced with prevailing local climatic conditions and the genetic makeup synchronized with the rhythm of the changes in the climatic conditions. Species which have arrived recently and have only had experience with the climatic conditions for a few generations are not expected to be well adapted to local conditions. In Britain pines, birch, juniper and alders are expected to be better adapted than the recently arrived ash.

\section{History of Scots pine (Pinus sylvestris) in Scotland}

Scots pine (Pinus sylvestris) is the most widely distributed conifer species in the world. Its distribution extends from the far north of Finland to Spain and from Western Scotland to Siberia [34] and it is the only pine species native to Britain. During the last glaciation Scotland was covered with ice and Scots Pine was probably entirely eradicated $[35,36]$. Following the retreat of the ice, Scots pine reached Britain about 10,500 years ago [36] and Scotland 9000 years ago. Forests dominated by Scots pine covered as much as 1.5 million ha of the north-central highlands of Scotland some 4400 years ago [23]. Exploitation and inappropriate management over many centuries reduced the area of Scots pine population to $\sim 19,759$ ha at the end of the twentieth century. The oldest Scots pine recorded in Britain was 395 years old [37]. From being the largest component of Scottish forests before 5000 years ago, the area of Scots pine forest has been reduced to less than $1 \%$ of its original extent. due to direct and indirect effect of human beings such as overgrazing by sheep, deer and cattle, unsustainable management for timber and overexploitation. Between seventeenth and nineteenth centuries [37] various use of Scots pine forest have shrunk the area, such as exploitative felling [37], conversion for deer grazing and cattle rearing and finally felling during First and Second World War [38]. Being a national timber of the Scotland, cultivated and noted for its timber properties, Scots pine has been used for various purposes from furniture to construction. At the same time it has aesthetic value as both a living and harvested tree, for example, a special use of Scots pine is as Christmas trees.
During the early period of 18 th century Scots pine was tested as a valuable tree for plantation. Scots pine from Scotland is considered by various authorities as having races, varieties or subspecies [6]. Scottish Scots pine is known as Pinus sylvestris $L$ var Schotta Apart from this a number of synonyms have been used for this species. A timber merchant Mr. George Don between 1814-1817 divided Scots pine into four varieties to identify the better performing varieties and increase business at that time. According to him there are four varieties based on phenological characters like leaves size, colour, cone size and arrangement, branch characters and roughness of bark. Those varieties were:

- Pinus sylvestris L var horizontalis Don

- Pinus sylvestris L var vulgaris Don

- Pinus sylvestris L var uncinata Don

- Pinus sylvestris L var tortuosa Don

Among these varieties Pinus sylvestris $\mathrm{L}$ var horizontalis Don is known for its performance and as suitable for plantation cultivation purposes. General attributes of this variety are horizontal branches with a tendency to bend near the trunk, rough bark, broad and serrulated leaves and thicker, smoother, less pointed cones. This variety is also tolerant of a wide range of soils and sites.

\section{Silviculture of Scots Pine}

\section{Distribution in Scotland}

Scots pine trees are to be found scattered through the northern mainland of Scotland from latitude $55^{\circ} \mathrm{N}$ to $57^{\circ} \mathrm{N}$ and from latitude $3 \mathrm{oW}$ to $1 \mathrm{oW}$ predominantly confined to areas of Moine basic geology. Figure I below displays distribution of Scots pine in Eurasia. There are no native pinewoods on the Hebrides or on Orkney, although pollen records suggest that Scots pine occurred in the western islands after the last glaciation. Scots pine is the only pine species to occur naturally in Britain and its pollen and macrofossil remains have been detected from all interglacial and many of the warmer interludes within glacial periods [23]. Native pine woods can be found at elevations from near sea level on the west coast (e.g. Loch Maree islands) to over $550 \mathrm{~m}$ above sea level (ASL) above Rothiemurchus in Strathspey. In Scotland, large populations of good and usable trees are available in Abernethy, Rothiemurchus and Glen Tanar [38].

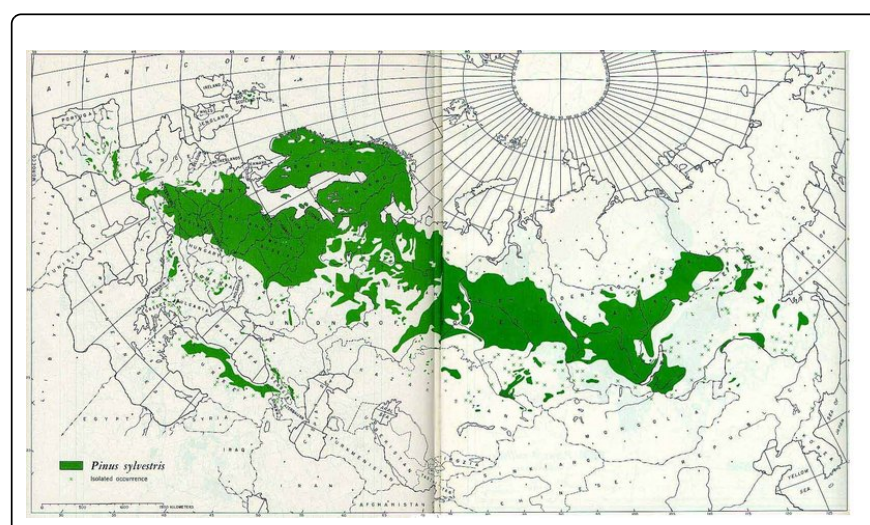

Figure 1: Distribution of Scots pine in the Eurasia (Europe and Asia) 
Page 4 of 6

Source: Geographic distribution of the pines of the world, USDA Forest Service Miscellaneous Publication. Page: 991, 1966.

These populations lie at the extreme north-west of the distribution and are physically separated by at least $500 \mathrm{~km}$ from extant natural stands in continental Europe. In general the remnant native Scottish pine populations are fragmented and isolated, but significant seminatural woodlands also exist, the history of which extends back to the end of glaciation [37].

\section{Phenology of Scots pine}

Scots pine is a monoecious tree in which both male and female sexes are present in the same tree. It is two needled pine with the leaf surrounded by a common sheath. It a tree of monopodial growth, i.e. growth upwards from single point and has only one single main stem, with the branches produced in whorls with no lateral bud and buds between whorls. Shoots vary in colours from green to green brown in first season, maturing to greyish-brow and later to orange or red brown. Bud is up to $12 \mathrm{~mm}$ in long, oblong ovoid, resinous generally red- grey- brown, rarely red. It attains an average height of $15-30 \mathrm{~m}$ and reaches maximum height of $46 \mathrm{~m}$.

Formation of root is variable based on the soil type, soil temperature and moisture content. It is normally shallow, pale in colour without any prominent tap root. Root and shoot growth occurs in late March or early June. Walter HL, Brayton FW [39] found in the first year the root growth starts 16-18 days after formation of needles and when the soil temperature is $12^{\circ} \mathrm{C}$. In the subsequent years root growth begins before shoot growth and reaches a maximum during summer and decrease in August and September. The mean shoot: root ratio in Scots pine is 2:7 and increases with age.

Frost is common phenomenon in the Scots pine life cycle. It is tolerant of both early and late frosts, but this varies with provenance. Photoperiod is one of the crucial factors for rate of growth, internodes enlargement, leaf number, leaf length and cambial activity. Exposure to long days prolongs active growth or increases rate of growth (or both) whilst exposure to short days curtails growth and speed up the commencement of dormancy. Height increase is achieved by extension of internodes initiating at the bud (Figure 2).

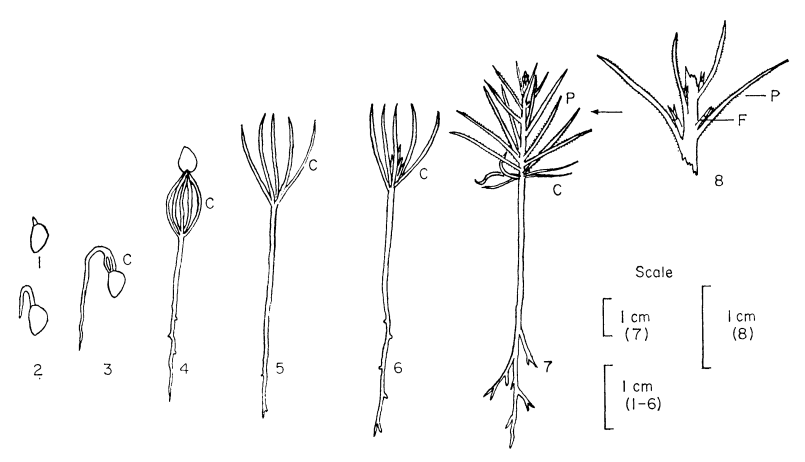

Figure 2: The development of the Pinus sylvestris L seedling in the 6-8 months following germination.

C -Cotyledons, P- primordial leaves; F-biflorial fascicles. Numbers 1-8 represents the sequence of time. Source: Carlisle, A. and A. H. F. Brown [39].

\section{Climatic requirement}

The native pine of Scotland occurs in a limited geographic area of British Isles, i.e. $160 \mathrm{~km}$ from Shieldaig in the west to Glen Tanar in the east; $180 \mathrm{~km}$ from Glen Falloch in the south to Rhidorroch in the north. These areas of the Scottish mainland receive average temperature of $230 \mathrm{oc}$ or below. While analyzing the distribution map based on Ecological Site Classification, majority of the native pine forest falls under cool-wet climatic zone. In exceptional cases Scots pine occur in sub-alpine climatic zone. For an example, at Creag Fhiaclach in the Cairngroms above Rothiemurchus, Scots pine forms a natural tree line at 550-520 m altitude. But they hardly reach $2 \mathrm{~m}$ in height. In the case of northern slopes above Glenmore, a Scots pine dominated scrub zone is developing at an elevation of 600-700 m, due to reduced deer browsing. Scots pine is able to withstand minimum temperature of $-26.7^{\circ} \mathrm{C}$.

\section{Soil types of Scots pine}

Scots pines grow well on freely draining mineral soils. Within some larger woodland, patches of wooded bog can be found. In general Scots pine is common on peaty iron pans, sandy podzols to shallow rendzians and shallow acid peats. But Scots pines also found on deeper peats where they are stunted and slow growing. Scots pine likes to grow on strongly podzolised soils with well-developed litter layer overlying more humus. Rodwell et al. [40] have classified Scots pine into two. First is, 'healthy acid pine woods' which is naturalised with presence of ericaceous shrub, lime avoiding herbaceous species and various mosses on the ground level. Second is calcicolous pine wood which is less common with lime loving shrubs and herbaceous species. In afforestation, phosphate fertilisers are added to the afforesting area at the rate of $60 \mathrm{~kg} / \mathrm{ha} \mathrm{[41]} \mathrm{and} \mathrm{application} \mathrm{of} \mathrm{nitrogen} \mathrm{nutrient} \mathrm{at} \mathrm{the}$ pole stage shows improved growth rate [42].

\section{Adaptation by Scots Pine (Pinus sylvestris)}

The Scottish Scots pine is morphologically, anatomically heterogeneous and the variation appears to be continuous. Among the variable characters are habits, bark, leaf colour leaf length and cone form. In present-day Scotland, Scots Pine is found from sea level to the natural tree line at over $600 \mathrm{~m}$ and adapted to rainfall from $3 \mathrm{~m} / \mathrm{yr}$. at sites on northwest coast to less than $800 \mathrm{~mm} / \mathrm{yr}$. on Speyside [38]. These forests are created the most westerly borders of Scots pine in Europe [24] and are considered genetically distinctive from the European population, potentially due to local adaptation subsequent to recolonisation since the last glacial period 10,000 years ago [25]. Generally, researchers have divided Scots pine into two, northern populations and southern populations. Rehfeldt et al. [30] carried out a provenance test with majority of Eurasian (Europe and Asia) population, covering majority of the distribution area. He concluded that seedlings growing in the far north have higher wood productivity and survival rate compared to southern populations. Present day populations have been found to contain significant genetic variation [24]. For instance pines in the oceanic climatic regions have thick branches and flexible or bendy trunks. At the same time those in northern and colder zones have thin branches and straight boles [43].

In Scots pine (Pinus sylvestris) variation within the species in cold hardiness is common during growing season [44] as in Betula pentula [45]. In another example, Douglas-fir starts stem growth as early as February [17] and bud swelling continues through March, but bud flush is not predictable as it may not until end of April or even May. 
However, mitotic activity is not easy to identify by sight. So the timing of the bud flush is often used as an indicator of adaptability. As Scots pine is adapted to various climatic conditions various eco types are evolved. Caledonian pines are often known as variety scotica occurs at far most extreme north-western edge of natural distribution and it is expected significantly distinct from other varieties.

\section{Latitude effect}

Various experiments have shown that northern Scots pine have greatest variation in growth and hardiness traits, exhibiting a clinal trend associated with latitude of seed origin [1]. Furthermore, northern origin material shows earlier growth cessation, shorter tree height and higher hardiness. But no important effect of altituderelated issues like survival and autumn cold hardiness were found, in studies of artificial freezing.

\section{References}

1. Langlet O (1971) Two hundred years of genecology. Taxon 20: 653-722.

2. Hedrick PW (2005) A standardized genetic differentiation measure. Evolution 59: 1633-1638.

3. Kawecki TJ, Ebert D (2004) Conceptual issues in local adaptation. Ecology Letters 7: 1225-1241.

4. Linhart YB (1999) Variation In Woody Plants: Molecular Markers, Evolutionary Processes And Conservation Biology. Kluwer Academic Publishers: 341-374.

5. Howe GT, Davis J (1999) Physiological and genetic approaches to studying endodormancy-related traits in Populus. Hortscience 34 1174-1184.

6. Williams CG, Savolainen O (1996) Inbreeding depression in conifers: Implications for breeding strategy. Forest Science 42: 102-117.

7. Petit RJ, Hu FS, Dick CW (2008) Forests of the Past: A Window to Future Changes. Science 320: 1450-1452.

8. Mimura M, Aitken SN (2007) Adaptive gradients and isolation-bydistance with postglacial migration in Picea sitchensis. Heredity 99: 224-232.

9. Silim SN, Lavender DP (1994) Seasonal patterns and environmental regulations of frost hardiness in shoots of seedlings of Thuja plicata, Chamaecyparis nootkatensis, and Picea glauca. Can J Bot 72: 309-316.

10. Hamrick JL (2004) Response of forest trees to global environmental changes. Forest Ecology and Management 197: 323-335.

11. Gonzales E, Hamrick JL, Smouse PE, Dyer RJ (2006) Pollen-mediated gene dispersal within continuous and fragmented populations of a forest understorey species, Trillium cuneatum. Mol Ecol 15: 2047-2058.

12. Sakai A, Larcher W (1987) Frost survival of plants. Spriger-Verlag Berlin.

13. Bigras FJ, Ryyop A, Stattin E (2001) Cold accimilation and deaccimilation of shoots and roots of conifer seedling. In Conifer cold hardiness. Edited by F.J. Bigras and S.J.Columbo. Kulwer Acadamic pblishers, Dordrech, The Netherlands: 55-88.

14. Chuine I, Beaubien EG (2001) Phenology is a Major Determinant of Tree Species Range. Ecology Letters 4: 500-510.

15. Fuchigami LH, Evert DR, Weiser CJ (1971) A Translicatable Cold Hardiness Promoter. Plant Physio 47: 837- 845.

16. Kramer PJ, Kozlowski TT (1979) Physiology of Woody Plants. Academic press. New York.

17. Fileder P, Owens JN (1989) A comparative study of shoot and root development of interior and coastal Douglas-fir seedlings. Can J For Res 19: 539-549.

18. Barnes BV, Zak DR, Denton SR, Spurr SH (1998) Forest Ecology. John Wiley \&Sons, New York.

19. Adams WT, Bastien JC (1994) Genetics of Second Flushing in a French Plantation of Coastal Douglas -Fir. Silvae Gent 43: 345-352.
20. Schermann N, Adams WT, Aitken SN, Bastien JC (1997) Genetic Parameters of Stem Form Traits in a 9 Year-Old Costal Douglas-Fir Progeny Test in Washington. Silvae Genet 46: 166-170.

21. Rehfelt G, Hoff EM, Steinhoff RJ (1984) Geographic pattern of genetic variation in Pinus moniculata. Bot Gaz 0145: 229-239.

22. Rehfeldt GE (1989) Ecological adaptations in Douglas-fir (Pseudotsuga menziesii var. glauca): a synthesis. Forest Ecology and Management 28: 203-215.

23. Bennett KD (1995) Post-glacial dynamics of pine (Pinus sylvestris) and pinewoods in Scotland. Scottish Natural Heritage. J. R. Aldhous. Edinburgh, Forestry Commission, The Royal Society for the Protection of Birds: 23-39.

24. Ennos RA, Worrell R, Malcolm DC (1998) The genetic management of native species in Scotland. Forestry 71: 1-23.

25. Kinloch BB, Westfall RD (1986) Caledonian Scots pine - origins and genetic structure. New Phytol 104: 703-729.

26. Slatkin M (1985) Gene Flow in Natural Populations. Annual Review of Ecology and Systematics 16: 393-430.

27. Carter KK (1996) Provenance tests as indicators of growth response to climate change in 10 north temperate tree species. Canadian Journal of Forest Research 26: 1089-1095.

28. Rehfeldt GE, Ying CC (1999) Genetic Responses to Climate in Pinus Contorta: Niche Breadth, Climate Change, and Reforestation. Ecological Monographs 69: 375-407.

29. Garcia-Ramos G, Kirkpatrick M (1997) Genetic Models of Adaptation and Gene Flow in Peripheral Populations. Evolution 51: 21-28.

30. Rehfeldt GE, Tchebakova NM (2002) Intraspecific responses to climate in Pinus sylvestris. Global Change Biology 8: 912-929.

31. Wang T, Hamann A (2006) Use of response functions in selecting lodge pole pine populations for future climates. Global Change Biology 12: 2404-2416.

32. Andalo C, Beaulieu J (2005) The impact of climate change on growth of local white spruce populations in Quebec, Canada. J For Ecol Manag 205: 169-182.

33. Howe GT, Aitken SN (2003) From genotype to phenotype: unraveling the complexities of cold adaptation in forest trees. Canadian Journal of Botany-Revue Canadienne De Botanique 81: 1247-1266.

34. Critchfield WB, Little E (1966) Geographic distribution of the Pines of the world, U.S. Department of Agriculture: 97.

35. Huntley B, Birks HJB (1983) An Atlas of Past and Present Pollen Maps for Europe: 0-13000 Years Ago. Cambridge, Cambridge University Press.

36. Bennett KD, Tzedakis PC (1991) Quaternary refugia of North European trees. Biogeogr 18: 103-115.

37. Steven HM, Carlisle A (1959) The Native Pinewoods of Scotland. Edinburgh, Oliver and Boyd.

38. Mason WL, Hampson A (2004) Managing the Pinewoods of Scotland. Edinburgh, Forestry Commission.

39. Walter HL, Brayton FW (1966) Controlled Growth of Forest Tree Roots: Techniques and Application. Harvard Forest Paper: 16.

40. Rodwell JS (1995) British Plant Communities. Volume 4. Aquatic communities, swamps and tall-herb fens. Cambridge University Press.

41. Taylor C (1993) Report on the Activities of the Native Pinewood Managers. Scottish Forestry 48: 102-109.

42. McIntosh B (2006) Native pinewoods in Scotland: perspectives on policy and management. Forestry 79: 303-307.

43. Kujala V (1958) Männyn suku. Suuri kasvikirja I. J. Jalas, Otava: 142-152.

44. Hurme P, Repo T (1997) Climatic adaptation of bud set and frost hardiness in Scots pine (Pinus sylvestris). Canadian Journal of Forest Research-Revue Canadienne De Recherche Forestiere 27: 716-723.

45. Li C, Junittila OHP, Palva ET (2003) Different responses of Northern and southern ecotypes of Betula pendula to exogenous ABA application. Tree Physiol 23: 481-487. 